\title{
Serum gentamicin assay: A comparison and assessment of different methods
}

\author{
I. PHILLIPS, CHRISTINE WARREN, AND S. E. SMITH
}

From the Departments of Microbiology and Pharmacology, St Thomas's Hospital Medical School, London

SYNOPSIS We have compared, in a clinical laboratory, three methods for estimating the concentration of gentamicin in serum. The adenylase method is most accurate, but requires considerable skilled technical time and expensive apparatus. The urease method requires an accurate $\mathrm{pH}$ meter but is otherwise inexpensive, but in our hands, although it produces results most rapidly, it also requires considerable technician time and is least accurate. The agar diffusion method requires no expensive apparatus, least technician time, and produces results of acceptable accuracy. It does, however, take longer than the other two methods to produce results.

During recent years several new methods have been introduced for the assay of antibacterial substances in serum in hospital laboratories. This paper describes a comparison in a clinical laboratory of the adenylase method of Smith, van Otto, and Smith (1972), the urease method of Noone, Pattison, and Samson (1971), and an agar-diffusion plate method, variants of which are used in most clinical laboratories for the assay of gentamicin.

\section{Materials and Methods}

Standards were prepared in pooled normal human serum to produce a series of seven concentrations from $0.625 \mu \mathrm{g} / \mathrm{ml}$ to $40 \mu \mathrm{g} / \mathrm{ml}$.

Serum samples were collected from patients receiving gentamicin therapy in St Thomas' Hospital, and assay results were used in dosage control.

\section{ADENYLASE METHOD}

Patient sera in duplicate and standard sera in triplicate were assayed by the method of Smith, van Otto, and Smith (1972). Adenylase was prepared from Esch. coli JR76 supplied by Dr J. Davies. Adenosine-8-14 C-5'-triphosphate sodium salt (CFA 426, batch $13 ; 1.02 \mathrm{mCi} / \mathrm{mmol}$ ) was obtained from the Biochemical Centre, Amersham. Radioactivity was measured in a liquid scintillation spectrometer.

PLATE (AGAR DIFFUSION) METHOD

Large, flat-bottomed glass assay dishes were filled to a depth of approximately $5 \mathrm{~mm}$ with Difco anti-

Received for publication 5 March 1974. biotic medium no. 5 seeded with a strain of Serratia marcescens obtained from Dr D. Reeves. Wells of $7 \mathrm{~mm}$ diameter were filled with standard and patient sera in duplicate, and the plate was held for two hours at room temperature and then incubated at $37^{\circ} \mathrm{C}$ for 18 hours, when the diameters of zones of growth inhibition were measured to the nearest 0.5 $\mathrm{mm}$.

UREASE METHOD

Serum gentamicin concentrations were assayed by the method of Noone et al (1971) using Proteus mirabilis BS711 provided by Dr Noone. Following incubation, the $\mathrm{pH}$ of the medium was measured with a Pye model $78 \mathrm{pH}$ meter, using a Pye electrode type $401 \mathrm{E7}$, and curves were drawn from which the gentamicin concentration in the samples could be estimated.

\section{STATISTICAL METHODS}

Measurements obtained in the investigation of standards were subjected to analysis of variance (Snedecor and Cochran, 1967) to test their reliability. Repeatability of assay results with serum from patients and correlations between the three assay methods were assessed by intraclass correlations (Fisher, 1970).

\section{Results}

MEASUREMENTS OF STANDARDS

Results of gentamicin assays by the three methods are illustrated in figs 1 (adenylase method), 2 (plate method), and 3 (urease method). In each figure the 


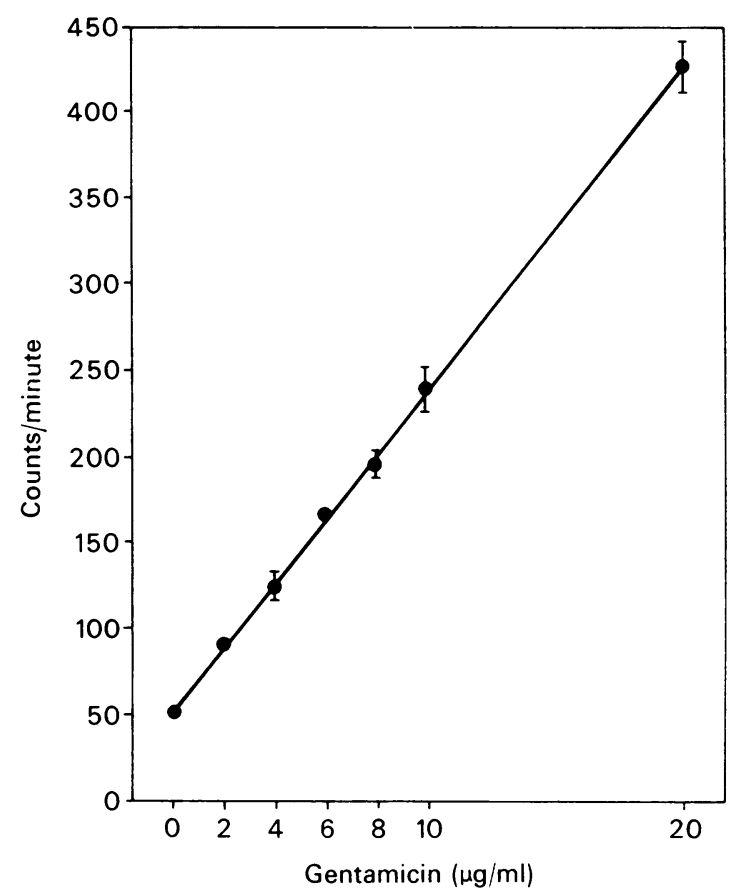

Fig 1 Determination of gentamicin standards by adenylase method. Points and vertical lines indicate mean $\pm S D$ radioactivity.

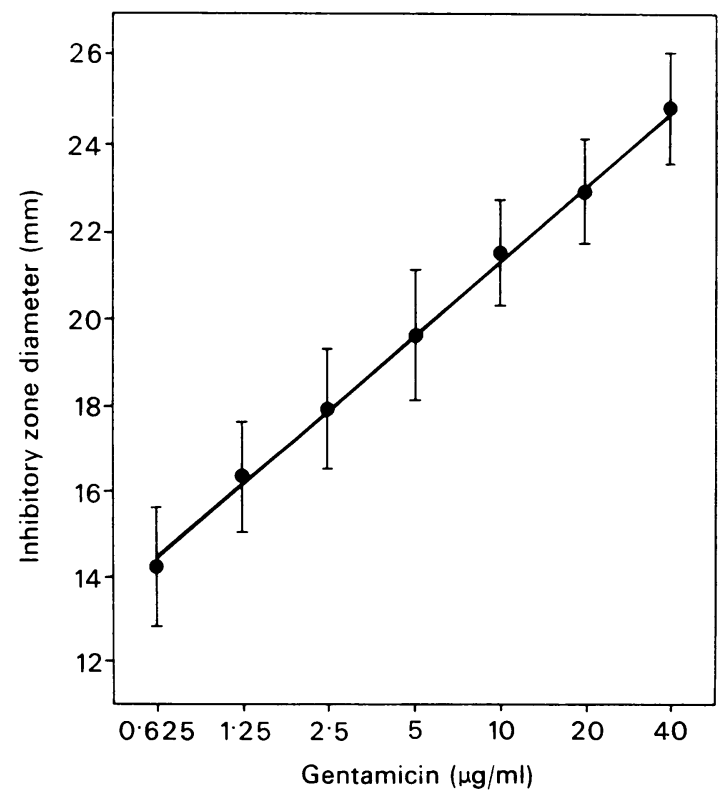

Fig 2 Determination of gentamicin standards by plate method. Points and vertical lines indicate mean \pm $S D$ diameter of zone of growth inhibition.

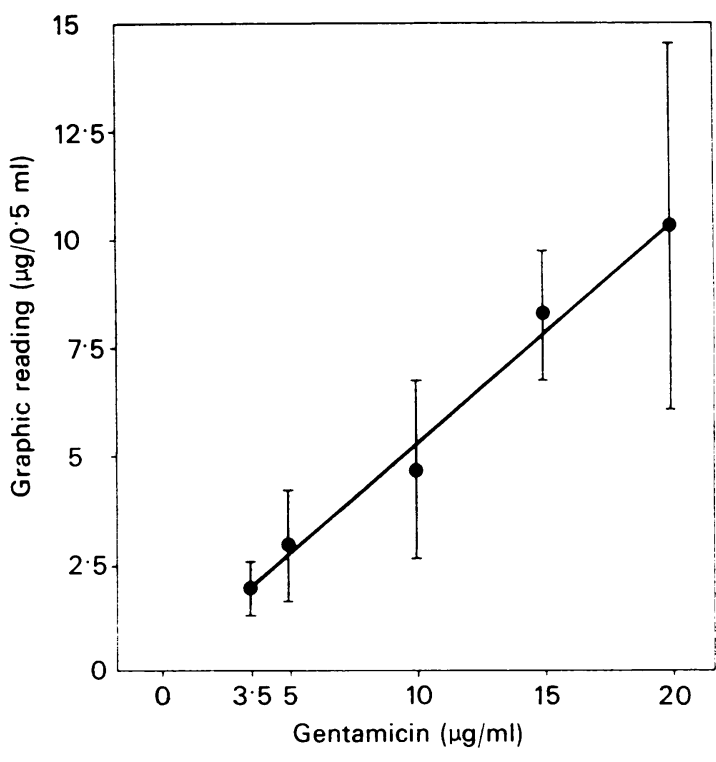

Fig 3 Determination of gentamicin standards by urease method. Points and vertical lines indicate mean $\pm S D$ graphic reading of concentration.

extent of the vertical lines, representing \pm 1 standard deviation of the individual determinations, indicates the variability of measurements obtained. This variability is attributable to different sources, as indicated by the analysis of variance shown in table I.

ADENYLASE METHOD

In this method the variance attributable to the regression of radioisotope counts on gentamicin concentration accounts for more than $99 \%$ of the total variance and the contributions of isotope counting errors, sample, and experimental replication are insignificant. This finding and the very high value of the variance ratio of the regression itself $\left(F_{5}^{1}=6900, P<0.001\right)$ indicate a high degree of reliability of the method. Further, the insignificant $N$ contribution of variability between samples and experiments indicates that standard sera need not $N$ be run on each occasion that assays are done for $\mathbb{\omega}$ clinical purposes, provided that one standard $\underset{2}{\sigma}$ curve has been prepared using the enzyme and ATP 0 in current use.

PLATE METHOD

In this method the variance attributable to the regression of growth-free zone diameters on gentamicin concentration accounts for $88 \%$ of the total variance. A further $10 \%$ is contributed by differences between experiment $\left(\mathrm{F}_{5}^{35}=11.49, \mathrm{P}<0.01\right)$, which 


\begin{tabular}{|c|c|c|c|c|c|}
\hline Method & Source of Variance & Sum of Squares & $\begin{array}{l}\text { Degrees of } \\
\text { Freedom }\end{array}$ & Mean Square & $F$ \\
\hline \multirow[t]{2}{*}{ Adenylase } & $\begin{array}{l}\text { Isotope counting } \\
\text { Sample replication } \\
\text { Between experiments } \\
\text { Regression } \\
\text { Residual }\end{array}$ & $\begin{array}{r}936 \cdot 8 \\
4415 \cdot 0 \\
1085 \cdot 9 \\
1098 \begin{array}{r}304 \cdot 7 \\
795 \cdot 8\end{array}\end{array}$ & $\begin{array}{r}42 \\
28 \\
7 \\
1 \\
5\end{array}$ & $\begin{array}{r}22 \cdot 3 \\
157 \cdot 7 \\
155 \cdot 7 \\
109804 \cdot 7 \\
159 \cdot 2\end{array}$ & $\begin{array}{c}0.14 \\
0.99 \\
0.97 \\
6900 \cdot 37^{4} \\
-\end{array}$ \\
\hline & Total & $1105538 \cdot 2$ & 83 & & \\
\hline \multirow[t]{2}{*}{ Plate } & $\begin{array}{l}\text { Sample replication } \\
\text { Between experiments } \\
\text { Regression } \\
\text { Residual }\end{array}$ & $\begin{array}{r}22.63 \\
110.81 \\
1011 \cdot 57 \\
1 \cdot 38\end{array}$ & $\begin{array}{r}42 \\
35 \\
1 \\
5\end{array}$ & $\begin{array}{r}0.54 \\
3 \cdot 17 \\
1011 \cdot 57 \\
0 \cdot 28\end{array}$ & $\begin{array}{c}1.95 \\
11.49^{1} \\
3670.44^{2} \\
-\end{array}$ \\
\hline & Total & $1146 \cdot 39$ & 83 & & \\
\hline \multirow[t]{2}{*}{ Urease } & $\begin{array}{l}\text { Sample readings } \\
\text { Sample replication } \\
\text { Regression } \\
\text { Residual }\end{array}$ & $\begin{array}{r}320 \cdot 00 \\
44 \cdot 17 \\
719 \cdot 52 \\
8 \cdot 06\end{array}$ & $\begin{array}{r}78 \\
10 \\
1 \\
3\end{array}$ & $\begin{array}{r}4 \cdot 10 \\
4 \cdot 42 \\
719 \cdot 52 \\
2 \cdot 69\end{array}$ & $\begin{array}{c}1.53 \\
1.64 \\
267.81^{*} \\
-\end{array}$ \\
\hline & Total & $1091 \cdot 75$ & 92 & & \\
\hline
\end{tabular}

Table I Analysis of variance in results of determination of gentamicin standards by three methods

${ }^{1} \mathbf{P}<0.01$

$s_{P}<0.001$

indicates significant differences in the measurement of standards between different plates. This finding underlines the necessity of replicating standard sera on each occasion that assays are done. Nevertheless, the variance ratio of the regression is very high $\left(F_{5}^{1}=3670, P<0.001\right)$. Within experiments, therefore, the reliability of the method is highly satisfactory.

\section{UREASE METHOD}

In this method, the regression of measurements (taken from the gentamicin concentration $\mathrm{v}$. pH graphs) on gentamicin concentration accounts for $66 \%$ of the total variance. A further $30 \%$ is contributed by differences in the readings obtained within samples, though this contribution is statistically insignificant in terms of the residual variance $\left(\mathrm{F}_{3}^{78}=1.53, \mathrm{P}<0.1\right)$. The implication of this finding is that taking a large number of readings does not improve the accuracy of the method. The variance ratio for the regression $\left(\mathrm{F}_{3}^{1}=268, \mathrm{P}<\right.$ 0.001 ) is highly significant, but the value indicates that the method is substantially less reliable than the adenylase or plate methods.

A comparison of the reliability of the three methods as assessed from the above data is shown in table II. In each case the coefficient of variation was calculated from the analysis of variance after elimination of variance due to regression and, in the

\begin{tabular}{lcl}
\hline Method & $\begin{array}{l}\text { Coefficient of } \\
\text { Variation (\%) }\end{array}$ & $\begin{array}{l}\text { Limits Enclosing } \\
95 \% \text { of Data }\end{array}$ \\
\hline Adenylase & $5 \cdot 1$ & $10 \%$ \\
Plate & $3 \cdot 6$ & $7 \%$ \\
Urease & 46.0 & $92 \%$ \\
\hline
\end{tabular}

Table II Variability in the results of assay of gentamicin in standard sera case of the plate method, that due to differences between experiments.

No direct measurements have been made of the time taken at the bench for the three methods, but we believe that the plate method takes substantially less skilled time than either of the other two methods.

REPEATABILITY OF ASSAYS OF PATIENT SERA Repeatability of these assays by the adenylase and plate methods has been assessed by calculation of the intraclass correlation coefficients. For the adenylase method $r=0.97(n=15)$ with $95 \%$ confidence limits 0.93 and 1.00 . For the plate method $r=0.88$ ( $n=17$ ) with $95 \%$ confidence limits 0.70 and 0.95 . Insufficient serum was available for replication by the urease method.

\section{CORRELATIONS BETWEEN ASSAY RESULTS}

BY DIFFERENT METHODS

Forty-four sera from patients were assayed by both the adenylase and plate methods and 22 of these also by the urease method. A comparison of results between the methods has been made by calculation of intraclass correlation coefficients. The results, illustrated in figs 4,5 , and 6 , yielded the following coefficients:

\begin{tabular}{llll}
\hline Methods & $n$ & $r$ & $\begin{array}{l}95 \% \text { Confidence } \\
\text { Limits of } r\end{array}$ \\
\hline Adenylase v plate & 44 & 0.95 & $0.91-1.00$ \\
Adenylase v urease & 22 & 0.80 & $0.57-0.91$ \\
Plate v urease & 22 & 0.83 & $0.63-0.92$ \\
\hline
\end{tabular}

The correlation coefficient for the adenylase $\mathrm{v}$ plate methods is intermediate between those for each method alone. Comparisons involving the urease 


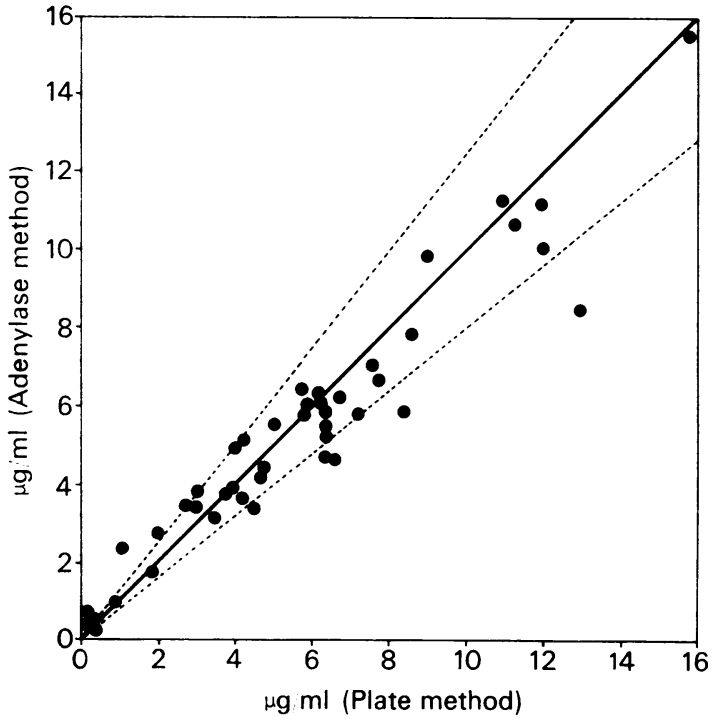

Fig 4

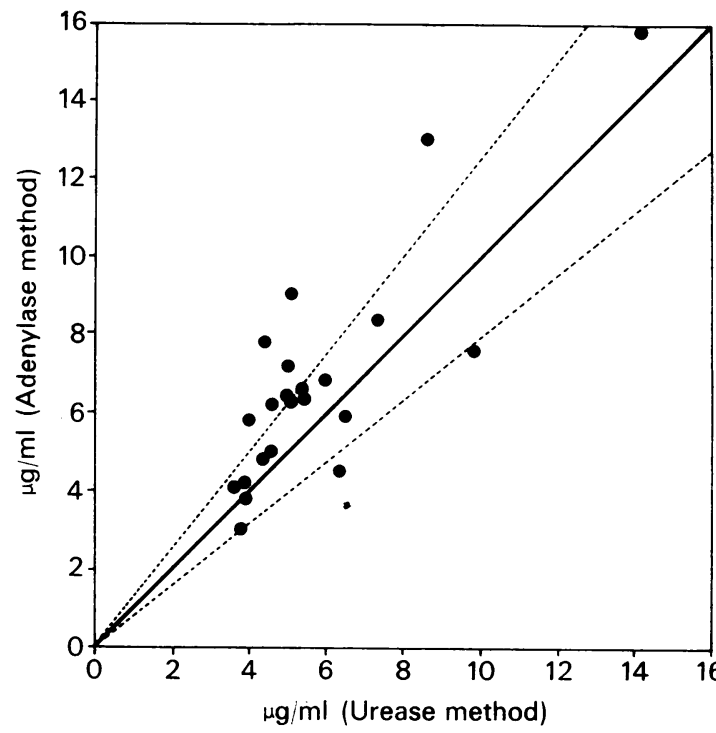

Fig 5

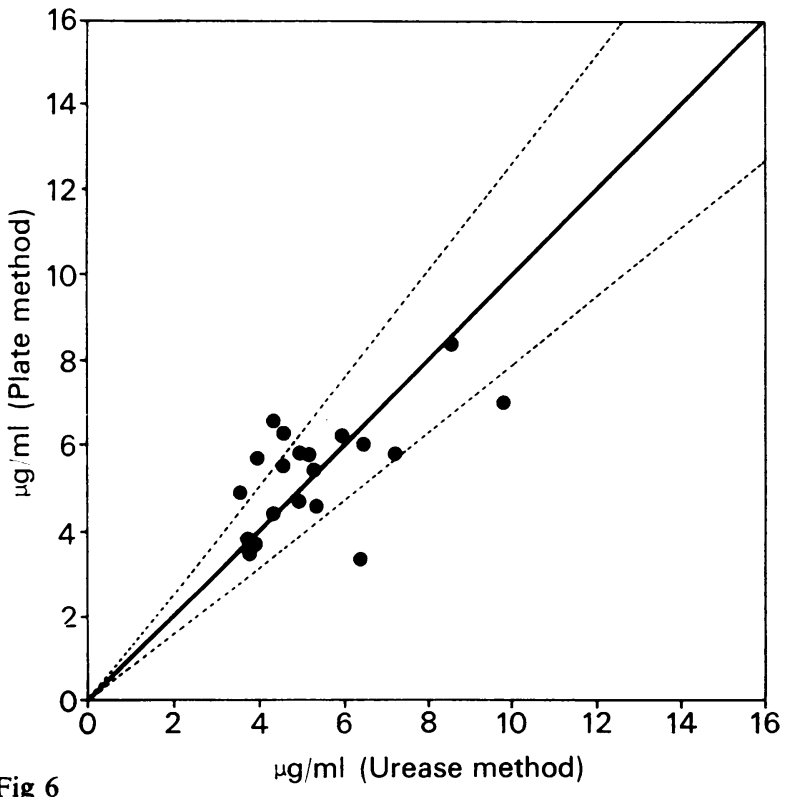

Fig 6
Fig 4 Double assay of 44 sera for gentamicin by adenylase and plate methods. Interrupted lines indicate $20 \%$ limits of error.

Fig 5 Double assay of 22 sera for gentamicin by adenylase and urease methods. Lines are as for figure 4.

Fig 6 Double assay of 22 sera for gentamicin by plate and urease methods. Lines are as for figure 4 method yielded lower coefficients, indicating less satisfactory agreement with this method. These results are consistent with the earlier findings that the adenylase and plate methods are substantially more reliable than the urease method.

\section{Discussion}

In order to be useful in a clinical laboratory, assay methods must be reasonably accurate-20\%accuracy is probably acceptable - must require a minimum of 
skilled technician time, must take account of availability of apparatus, and should ideally yield results within about five hours.

The adenylase method is by far the most accurate of the three but is also time-consuming in our hands, and requires a liquid scintillation spectrometer.

Of the three methods that we have used, we find the plate assay to be least time consuming, to require little apparatus not found in most laboratories, and to be sufficiently accurate for clinical use, provided it is performed by an experienced technician.

The urease method requires little apparatus not found in a clinical laboratory (mainly a pH meter reading accurately to one decimal place), but in our hands takes more time and organization than the plate method and is less accurate. Plotting of curves is intrinsically more liable to error than the plotting of straight lines. We have recently described a modification of this method that is rapid and probably accurate though it requires expensive apparatus (Bourne, Phillips, and Smith, 1974).

We therefore conclude that of the three the plate method best suits an ordinary clinical laboratory. It should be emphasized, however, that experience is essential, and it is possible that with more experience with the adenylase and urease methods we might become more efficient, and in the latter more accurate. Experience is more easily acquired for the plate method as it is applicable to the assay of a broader range of antibiotics - a further point in its favour.

The plate method is also the best suited to emergency use. The plate can be poured, and left in the refrigerator, with standards, so that all that remains is to make the wells and fill them with control and test sera. The urease and adenylase methods require more expertise in their setting up.

One further point that requires discussion is the time taken from receipt of specimens to the availability of results-in two and a half hours for the urease method, in three hours for the adenylase method, and in about 18 hours for the standard plate method. However, we have noted in other work that zones on plates are sufficiently distinct to be measurable after seven to eight hours' incubation, and that if a heavy inoculum of Serratia is used zones are readable after about four hours. Ideally, results are needed clinically within about five hours if a strict six hourly regimen is to be kept up, but because the dose interval is usually prolonged in patients with excretory failure, for whom serum assays are most often needed, we can manage most of them adequately. On occasion, however, it is very useful to have results more quickly.

We thank Dr D. Reeves, Southmead Hospital, Bristol, Dr P. Noone, Royal Free Hospital, and Dr J. Davies, Department of Biochemistry, University of Wisconsin, for assay organisms, and Mr D. Humphrey for preparing the adenylase.

\section{References}

Bourne, P. R., Phillips, I., and Smith, S. E. (1974). Modification of the urease method for gentamicin assays. J. clin. Path., 27, 168 169.

Fisher, R. A. (1970). Statistical Methods for Research Workers, 14th ed. Oliver and Boyd, London.

Noone, P., Pattison, J. R., and Samson, D. (1971). Simple rapid method for assay of aminoglycoside antibiotics. Lancet, 2, 16-19.

Smith, D. H., van Otto, B., and Smith, A. L. (1972). A rapid chemical assay for gentamicin. New Engl. J. Med., 286, 583-586.

Snedecor, G. W., and Cochran, W. G. (1967). Statistical Methods, 6th ed. Iowa State University Press, Ames, Iowa. 